\title{
INTEGRACYJNA KONCEPCJA ZRÓWNOWAŻONEGO ROZWOJU (IKoNE)
}

\author{
W artykule zaprezentowano mało znaną $w$ Polsce integracyjną koncepcje \\ zrównoważonego rozwoju (IKoNE), wypracowaną pod koniec lat dziewięćdziesiątych XX w. \\ przez Federację Niemieckich Ośrodków Badawczych im. Hermanna Helmholtza. Na tle ogólnej \\ charakterystyki metodologicznej omówiono przykłady udanych zastosowań tej koncepcji do \\ diagnozowania sytuacji rozwojowej Niemiec pod kątem głównych deficytów zrównoważoności \\ i poszukiwania ich rozwiązań. \\ Słowa kluczowe: zrównoważony rozwój, IKoNE.
}

\section{ZRÓWNOWAŻONOŚĆ JAKO NOWY PARADYGMAT ROZWOJOWY}

Pojęcie zrównoważonego rozwoju (ang. sustainable development, niem. nachhaltige Entwicklung) stało się obecnie obowiązkowym punktem w politycznych i administracyjnych agendach na wszystkich szczeblach stanowienia społeczeństwa, od międzynarodowych porozumień, przez krajowe i regionalne strategie rozwojowe, aż po gminne plany zagospodarowania i deklaracje przedwyborcze pojedynczych kandydatów. Z pojęcia orientującego na potrzeby globalnej polityki zaproponowanego przez Światową Komisję ds. Środowiska i Rozwoju (World Commission for Environment and Development) w raporcie Nasza wspólna przyszłość (tzw. Brundtland-Report) zrównoważony rozwój stał się paradygmatem, czyli uniwersalnym, przekrojowym wzorcem dobrej praktyki dla różnorodnych zastosowań. Rozumienie i wdrażanie zrównoważonego rozwoju w poszczególnych obszarach działalności człowieka istotnie utrudnia inflacyjne użycie tego terminu. Te typowe dla paradygmatów inflacyjność, ogólność, niekonkretność i nieostrość to cena, jaką płaci się za uniwersalny charakter takich wizji. „Zrównoważony rozwój”, tak jak inne paradygmaty, jest dynamicznym pojęciem, które otwiera rozległe możliwości interpretacji i którego treść podlega ciągłej aktualizacji. Ponieważ nie jest tworem czysto opisowym, ale normatywnym i regulatywnym, który odgrywa rolę nawigacyjną w działaniu, musi być nieustannie redefiniowana i na nowo konceptualizowana, w miarę jak w toku jej wdrażania pojawiaja się nowe zjawiska i problemy do rozwiązania. Aby uczynić ją uniwersalnym, poręcznym, miarodajnym, skutecznym i wydajnym kryterium działania i narzędziem obiektywnej, parametrycznej oceny działań tu i teraz, w różnych obszarach i różnych warunkach, należy nie tylko wyeksplikować elementy konstytutywne pojęcia „zrównoważoności”, ale przede wszystkim dokonać operacjonalizacji tego pojęcia, czyli powiązania tych ogólnych teoretycznych treści z empirycznym językiem specyficznym dla szczegółowych praktyk w formie specyficznych obszarowych systemów reguł i wskaźników ${ }^{2}$ (na przykład

\footnotetext{
${ }^{1}$ Dr Krzysztof Michalski, Zakład Nauk Humanistycznych, Wydział Zarządzania, Politechnika Rzeszowska.

${ }^{2}$ Por. T. Borys, $W$ poszukiwaniu syntetycznego wskaźnika zrównoważonego rozwoju, [w:] Obszary badań nad trwałym i zrównoważonym rozwojem, red. B. Poskrobko, Ekonomia i Środowisko, Białystok 2007, s. 271-292.
} 
zrównoważona konsumpcja, zrównoważona energetyka czy zrównoważona gospodarka przestrzenna $\mathrm{i}$ in.). W toku dwudziestoletniej debaty, jaka toczy się wokół tego paradygmatu na płaszczyznach międzynarodowych i krajowych, politycznych i naukowych, wypracowano szereg koncepcji zrównoważonego rozwoju, zróżnicowanych pod względem legitymizacji, operacjonalizacji czy potencjału implementacyjnego ${ }^{3}$. Jedną z takich prób konkretyzacji idei zrównoważoności jest koncepcja integracyjna zrównoważonego rozwoju (IKoNE, das integrative Konzept nachhaltiger Entwicklung) ${ }^{4}$, wypracowana pod koniec lat dziewięćdziesiątych XX w. przez Federację Niemieckich Ośrodków Badawczych im. Hermanna von Helmholtza (HGF, Helmholtz-Gemeinschaft der Deutschen Forschungszentren) w ramach projektu „Rozwój przyszłościowy globalnie. Perspektywy dla Niemiec".

$\mathrm{Na}$ architekturę koncepcji integracyjnej istotnie wpłynęła struktura tematyczna projektu. Ramy odniesienia koncepcji stanowią z jednej strony przyszłość świata, z drugiej pozycja i perspektywy rozwojowe Niemiec w zmieniającym się globalnym układzie politycznogospodarczym. Nadrzędnym celem badawczym projektu było dostarczenie normatywnie zreflektowanego naukowego ufundowania politycznej strategii zrównoważonego rozwoju Niemiec w postaci jednolitej treściowo wizji, szczegółowych celów, wskaźników, metod inwentaryzacyjnych i diagnostycznych do wykrywania deficytów oraz uniwersalnych rozwiązań ewentualnych problemów. Tło polityczne projektu stanowi dążenie do wykorzystania zrównoważonego rozwoju Niemiec do utrwalenia pozycji tego kraju na arenie globalnej jako spolegliwego partnera w międzynarodowych działaniach na rzecz rozwoju i stabilizacji ładu światowego, dążenie do wzrostu znaczenia Niemiec jako potęgi gospodarczej i dostawcy nowoczesnych technologii oraz do zapewnienia ludności wysokiego bezpieczeństwa socjalnego i wysokich wskaźników dobrobytu w wymiarze wielopokoleniowym. W projekt zaangażowanych było kilka renomowanych ośrodków badawczych o wysokiej doskonałości, między innymi Centrum Badawcze Karlsruhe (FZK, Forschungszentrum Karlsruhe), głównie Instytut Analizy Systemowej i Oceny Technologii (ITAS, Institut für Technikfolgenabschätzung und Systemanalyse), które koordynowało badania, ponadto Niemieckie Centrum Awioniki i Kosmonautyki (DLR, Deutsches Zentrum für Luft- und Raumfahrt), głównie Instytut Badań nad Transportem oraz wydział Oceny Technologii i Badań Systemowych przy Instytucie Termodynamiki Technicznej, Centrum Badawcze Jülich (FZJ, Forschungszentrum Jülich) i zespoły projektowe Człowiek-Środowisko-Technika (MUT, Mensch-Umwelt-Technik) i Badania Systemowe i Rozwój Technologiczny (STE, Systemforschung und Technikentwicklung) oraz Fraunhoferowski Instytut Autonomicznych Systemów Inteligentnych (AIS, Fraunhofer Institut für Autonome Intelligente Systeme) i Fraunhoferowski Instytut Architektury Komputerowej i Technik Programowania (FIRST, Fraunhofer-Institut für Rechnerarchitektur und Softwaretechnik) ${ }^{5}$.

\footnotetext{
${ }^{3}$ Przejrzysty przegląd najważniejszych koncepcji zrównoważonego rozwoju zob. J. Jörissen i in., Wissenschaftliche Konzeptionen zur Nachhaltigkeit, [w:] Forschungswerkstatt Nachhaltigkeit. Wege zur Diagnose und Therapie von Nachhaltigkeitsdefiziten, red. Grunwald A. i in., Edition Sigma, Berlin 2001, s. 33 58

${ }^{4}$ Por. J. Kopfmüller i in., Nachhaltige Entwicklung integrativ betrachtet. Konstitutive Elemente, Regeln, Indikatoren, Edition Sigma, Berlin 2001; Nachhaltigkeitsprobleme in Deutschland. Analyse und Lösungsstrategien, red. R. Coenen, A. Grunwald, Edition Sigma, Berlin 2003.

${ }^{5}$ Zob. Nachhaltigkeitsprobleme in Deutschland. Analyse und Lösungsstrategien..., s. 15 n.
} 


\section{ARCHITEKTURA KONCEPCJI INTEGRACYJNEJ}

Ze względu na swoje pragmatyczne cele koncepcja integracyjna stanowi wielopoziomową strukturę referencyjną obejmującą warstwę problemów podstawowych (Co oznacza „zrównoważony”?), warstwę operacjonalizacyjną (Jak mierzyć „Zrównoważoność” rozwoju?) w postaci systemu wskaźników, warstwę implementacyjno-diagnostyczną (Gdzie są problemy ze „zrównoważonością”?, Jakie są te deficyty?) oraz warstwę strategiczną o charakterze rekomendacyjnym (Jak rozwiązywać te problemy?, Jak uzyskać więcej „zrównoważoności”?). Poszczególne warstwy mają zróżnicowanych adresatów: naukowców zajmujących się badaniami szczegółowych aspektów zrównoważoności, decydentów ze świata polityki, pracowników administracji różnych szczebli, przedstawicieli biznesu, a także środki przekazu i publiczność zainteresowaną społeczną dyskusją tocząca się wokół zagadnień zrównoważonego rozwoju.

Na podstawie „Raportu Brundtland” i postanowień Szczytu Ziemi w Rio de Janeiro za elementy konstytutywne zrównoważonego rozwoju przyjęto sprawiedliwość między- i wewnątrzpokoleniowa, antropocentryczną etykę i globalną perspektywę. Pierwszy poziom operacjonalizacji stanowią trzy ogólne cele zrównoważonego rozwoju: (1) zapewnienie ludzkości bezpieczeństwa bytowego i ciagłości trwania życia ludzkiego na Ziemi; (2) utrzymanie społecznego potencjału twórczego oraz (3) zachowanie koniecznych warunków możliwości rozwoju i działania. Bez zapewnienia bezpieczeństwa bytowego ludzkości postulaty wszystkich teorii sprawiedliwości byłyby pozbawione fundamentu, bez zagwarantowania ciagłości społecznego potencjału twórczego i zachowania szans rozwoju i działania zaś przyszłe pokolenia znalazłyby się w gorszej sytuacji niż obecnie żyjący ludzie. Na podstawie takiego wnioskowania autorzy koncepcji integracyjnej uznali, że niespełnienie tych trzech podstawowych warunków uniemożliwia realizację zasady sprawiedliwości międzypokoleniowej, która stanowi konstytutywny element zrównoważonego rozwoju ${ }^{6}$.

Wymienione trzy fundamentalne cele zrównoważonego rozwoju skonkretyzowano w formie 15 reguł substancjalnych, podających minimalne substancjalne warunki konieczne zrównoważonego rozwoju oraz 10 reguł instrumentalnych, określających minimalne wymagania organizacyjno-instytucjonalne warunkujące realizację reguł substancjalnych. Minimalne substancjalne warunki konieczne bezpieczeństwa bytowego ludzkości (1) to ochrona zdrowia, zaopatrzenie na poziomie podstawowym, umożliwienie samodzielnego zabezpieczenia bytowego, sprawiedliwy dostęp do dóbr środowiskowych oraz kompensacja skrajnych dysproporcji dochodowych i majątkowych. Utrzymanie społecznego potencjału twórczego (2) wymaga zrównoważonego użytkowania zasobów odnawialnych i nieodnawialnych, zrównoważonego korzystania ze środowiska jako niszy, unikania nadmiernych ryzyk technologicznych oraz zrównoważonego rozwoju kapitału rzeczowego, kapitału ludzkiego i kapitału wiedzy. Natomiast zachowanie co najmniej dotychczasowego wolumenu możliwości rozwoju i działania (3) nie jest możliwe bez zagwarantowania równego dostępu do edukacji, zawodu i informacji, możliwości partycypacji w społecznych procesach decyzyjnych, zachowania dziedzictwa kulturowego

\footnotetext{
${ }^{6}$ Ibidem, s. 67.
} 
i różnorodności kulturowej, kulturowych funkcji przyrody oraz zachowania „zasobów społecznych" (tab. 1).

Tabela 1. Substancjalne wymogi minimalne zrównoważonego rozwoju w koncepcji integracyjnej

\begin{tabular}{|c|c|c|c|}
\hline $\begin{array}{l}\text { Cele } \\
\text { nadrzędne }\end{array}$ & $\begin{array}{l}\text { 1. Zabezpieczenie } \\
\text { bytowe ludności }\end{array}$ & $\begin{array}{l}2 . \quad \text { Utrzymanie } \\
\text { społecznego } \\
\text { potencjału } \\
\text { twórczego }\end{array}$ & $\begin{array}{l}3 . \quad \text { Zachowanie } \\
\text { możliwości } \\
\text { rozwoju i działania }\end{array}$ \\
\hline \multirow[t]{5}{*}{$\begin{array}{l}\text { Reguły } \\
\text { substancjalne }\end{array}$} & $\begin{array}{l}\text { 1.1. Ochrona } \\
\text { zdrowia ludzkiego }\end{array}$ & $\begin{array}{l}\text { 2.1. Zrównoważone } \\
\text { użytkowanie } \\
\text { zasobów } \\
\text { odnawialnych }\end{array}$ & $\begin{array}{l}\text { 3.1. Równość szans } \\
\text { w dostępie do } \\
\text { wykształcenia, } \\
\text { zawodu, informacji }\end{array}$ \\
\hline & $\begin{array}{l}\text { 1.2. Zaopatrzenie na } \\
\text { poziomie } \\
\text { podstawowym }\end{array}$ & $\begin{array}{l}\text { 2.2. Zrównoważone } \\
\text { użytkowanie } \\
\text { zasobów } \\
\text { nieodnawialnych }\end{array}$ & $\begin{array}{l}\text { 3.2. Partycypacja w } \\
\text { społecznych } \\
\text { procesach } \\
\text { decyzyjnych }\end{array}$ \\
\hline & $\begin{array}{l}\text { 1.3. Samodzielne } \\
\text { zabezpieczenie } \\
\text { bytowe }\end{array}$ & $\begin{array}{l}\text { 2.3. Zrównoważone } \\
\text { użytkowanie } \\
\text { środowiska jako } \\
\text { niszy }\end{array}$ & $\begin{array}{l}\text { 3.3. Zachowanie } \\
\text { dziedzictwa } \\
\text { kulturowego i } \\
\text { różnorodności } \\
\text { kulturowej }\end{array}$ \\
\hline & $\begin{array}{l}\text { 1.4. Sprawiedliwy } \\
\text { podział dóbr } \\
\text { środowiskowych }\end{array}$ & $\begin{array}{l}2.4 . \quad \text { Unikanie } \\
\text { nieuzasadnionych } \\
\text { ryzyk technicznych }\end{array}$ & $\begin{array}{l}\text { 3.4. Zachowanie } \\
\text { kulturowej funkcji } \\
\text { przyrody }\end{array}$ \\
\hline & $\begin{array}{l}\text { 1.5. Kompensacja } \\
\text { skrajnych } \\
\text { dysproporcji } \\
\text { dochodowych i } \\
\text { majątkowych }\end{array}$ & $\begin{array}{ll}2.5 . & \text { Zrównoważony } \\
\text { rozwój } & \text { kapitału } \\
\text { rzeczowego, kapitału } \\
\text { ludzkiego i } & \text { kapitału } \\
\text { wiedzy } & \end{array}$ & $\begin{array}{l}\text { 3.5. Zachowanie } \\
\text { zasobów } \\
\text { społecznych }\end{array}$ \\
\hline
\end{tabular}

Źródło: J. Kopfmüller i in., Nachhaltige Entwicklung integrativ betrachtet. Konstitutive Elemente, Regeln, Indikatoren, Edition Sigma, Berlin 2001, s. 172.

Minimalnymi warunkami organizacyjno-instytucjonalnymi, których spełnienie w wymiarze globalnym umożliwia realizację wymienionych reguł substancjalnych, są: internalizacja zewnętrznych kosztów społecznych i ekologicznych, adekwatne dyskontowanie, skuteczne rozwiązywanie problemów zadłużenia, uczciwe warunki w światowej wymianie gospodarczej, promowanie współpracy międzynarodowej, rezonans i zaangażowanie ze strony społeczeństwa, refleksyjność i samoświadomość społeczeństwa, odpowiedni potencjał sterujący społeczeństwa, samoorganizacja społeczeństwa i równowaga sił społecznych ${ }^{7}$. Reguły zrównoważoności uzupełnione zestawem szczegółowych wskaźników pełnią funkcję poręcznych, łatwych w użyciu, uniwersalnych kryteriów diagnostycznych do pomiaru zrównoważoności sytuacji i procesów rozwojowych oraz programów politycznych zarówno w wymiarze geograficznym (na płaszczyźnie globalnej, krajowej, regionalnej czy lokalnej), jak i w wymiarze problemowym i sektorowym (strategie rozwojowe, nowe technologie, energetyka etc.). Reguły obu typów - substancjalne i instrumentalne - mają raczej charakter kryteriów

${ }^{7}$ Ibidem, s. 20 n. 
negatywnych, minimalnych warunków koniecznych. Oznacza to, że ich spełnienie nie gwarantuje jeszcze osiagnięcia trzech generalnych celów i realizacji zrównoważonego rozwoju, natomiast niespełnienie jednego z kryteriów z góry dyskwalifikuje ocenianą sytuację lub proces $\mathrm{z}$ punktu widzenia zrównoważoności. Na potrzeby opisu i generalizującej oceny aktualnej sytuacji w Niemczech pod kątem zrównoważoności sporządzono wykaz 120 uniwersalnych, sektorowo niespecyficznych wskaźników przyporządkowanych do wymienionych 25 substancjalnych i instrumentalnych reguł zrównoważoności. Te wskaźniki uzupełniono podobną liczbą sektorowo specyficznych wskaźników, które szczegółowo inwentaryzuja poszczególne obszary działalności. Ze względów pragmatycznych, głównie dla ułatwienia komunikacji ze światem polityki i szerszą publicznością, tę obszerną listę wskaźników zredukowano do zestawu 40 wskaźników podstawowych, którym przyporządkowano wartości docelowe, nominalne dla kolejnych okresów rozwoju (lata 2010, 2020). Porównanie wartości docelowej, nominalnej z aktualną wartością wskaźnika pozwala zidentyfikować dystans do celu (distance-to-target) i ewentualne deficyty zrównoważoności i ich skalę pod kątem priorytetowych działań na potrzeby politycznego programowania rozwoju. Dzięki takiej diagnozie i ocenie sytuacji wiadomo, jakie są najpilniejsze potrzeby z punktu widzenia zrównoważonego rozwoju kraju i świata.

\section{SYTUACJA W NIEMCZECH I DEFICYTY ZRÓWNOWAŻONOŚCI}

$\mathrm{Na}$ podstawie takiego systemu diagnostycznego zidentyfikowano najważniejsze deficyty zrównoważoności występujące w Niemczech. Wyszczególniono je w tabeli 2 wraz z odzwierciedlającymi je wskaźnikami.

Tabela 2. Główne deficyty zrównoważoności w Niemczech oraz odzwierciedlające je wskaźniki

\begin{tabular}{|l|l|}
\hline Deficyt zrównoważoności & Wybrane wskaźniki \\
\hline Zagrożenia zdrowotne & $\begin{array}{l}\text { przekroczenia unijnych norm } \\
\text { mikropyłowego skażenia powietrza i } \\
\text { stężenia ozonu w warstwie przygruntowej } \\
\text { w wybranych stacjach pomiarowych } \\
\text { - odsetek ludności narażony na określony } \\
\text { poziom hałasu }\end{array}$ \\
\hline Ubóstwo & - skala ubóstwa \\
\hline $\begin{array}{l}\text { Drastyczne globalne dysproporcje } \\
\text { dochodach }\end{array}$ & $\begin{array}{l}\text { - globalna relacja między najwyższym a } \\
\text { najniższym kwintylem dochodów }\end{array}$ \\
\hline Bezrobocie & $\begin{array}{l}- \text { odsetek osób trwale bezrobotnych w } \\
\text { całkowitej liczbie bezrobotnych }\end{array}$ \\
\hline Braki w wykształceniu & $\begin{array}{l}- \text { odsetek osób bez ukończonej szkoły } \\
\text { głównej w całkowitej liczbie absolwentów } \\
\text { szkół }\end{array}$ \\
\hline Nierówność szans & $\begin{array}{l}\text { - uwarunkowanie kompetencji czytania u } \\
\text { uczniów ich sytuacją społeczno- } \\
\text { ekonomiczną }\end{array}$ \\
\hline Zużycie terenów & - dzienny przyrost powierzchni zajętych \\
\hline
\end{tabular}




\begin{tabular}{|c|c|}
\hline & $\begin{array}{l}\text { na osadnictwo i infrastrukturę } \\
\text { komunikacyjno-transportową }\end{array}$ \\
\hline Redukcja bioróżnorodności & $\begin{array}{l}\text { - odsetek gatunków zagrożonych } \\
\text { wyginięciem u ssaków, ptaków, ryb i } \\
\text { roślin naczyniowych }\end{array}$ \\
\hline $\begin{array}{l}\text { Obciążenie } \\
\text { leśnych }\end{array}$ & $\begin{array}{l}\text { - emisje zanieczyszczeń powietrza } \\
\text { powodujących zakwaszenie i eutrofizację } \\
\text { gleb }\left(\mathrm{SO}_{2}, \mathrm{NO}_{\mathrm{x}}, \mathrm{NH}_{3}\right)\end{array}$ \\
\hline Zużycie zasobów nieodnawialnych & $\begin{array}{l}\text { - zużycie nieodnawialnych surowców } \\
\text { energetycznych }\end{array}$ \\
\hline Zmiany klimatu & - emisje $\mathrm{CO}_{2}$ \\
\hline $\begin{array}{l}\text { Nierówny przydział możliwości } \\
\text { korzystania } \mathrm{z} \text { dóbr środowiska w skali } \\
\text { globalnej }\end{array}$ & $\begin{array}{l}\text { emisje } \mathrm{CO}_{2} \text { per capita } \\
\text { poszczególnych krajach }\end{array}$ \\
\hline Zanieczyszczenie wód & $\begin{array}{l}\text { - odsetek wód płynących mających co } \\
\text { najmniej II klasę czystości chemicznej }\end{array}$ \\
\hline Zadłużenie państw & - deficyt budżetowy państw \\
\hline $\begin{array}{l}\text { Niedostateczna świadomość globalnej } \\
\text { odpowiedzialności }\end{array}$ & $\begin{array}{l}\text { - zakres unijnych dopłat do eksportu w } \\
\text { sektorze rolnictwa } \\
\text { - środki publiczne na współpracę } \\
\text { rozwojową w procentach PKB }\end{array}$ \\
\hline
\end{tabular}

Źródło: Nachhaltigkeitsprobleme in Deutschland. Analyse und Lösungsstrategien, red. R. Coenen, A. Grunwald, Edition Sigma, Berlin 2003, s. 22.

Przyjęty na gruncie koncepcji integracyjnej system diagnostyczny ma uniwersalny charakter, to znaczy nadaje się do zastosowania w ocenie zrównoważoności sytuacji, działań i zjawisk w dowolnym obszarze aktywności społecznej i w dowolnej skali czasowej i przestrzennej. Obszary aktywności społecznej stanowią wzajemną kombinację określonej potrzeby społecznej (mobilność, mieszkalnictwo, żywienie, czas wolny itp.) oraz odpowiednich działań zaspokajających tę potrzebę (transport, budownictwo, rolnictwo, turystyka itp.). W zakres tych działań wchodzą zróżnicowane segmenty z całymi łańcuchami życiowymi różnie wyznaczające rozpiętość tych działań. Na przykład w wypadku obszaru „mobilność i transport” paleta sięga od wyrobu pojazdów i produkcji paliw po budowę i utrzymanie infrastruktury: kolejnictwo, drogownictwo itd. W projekcie HGF skupiono się na czterech, wymienionych w nawiasach, obszarach aktywności społecznej. Uznano, że te obszary, jeśli zostaną potraktowane razem, mają wysoki potencjał wyjaśniający dla zrozumienia istoty problemów zrównoważoności na płaszczyźnie środowiskowej (gospodarka zasobami) czy społecznej (sfera zatrudnienia). Sieciowe współzależności w tych obszarach i wzajemne powiązania między czynnikami determinującymi rozwój w tych obszarach dostarczają wiedzy nie tylko o naturze samych tych sektorowo specyficznych procesów, ale i o tym, jak te procesy wzajemnie się warunkują i sprzęgają oraz jak w ten sposób pogłębiają i pogarszają całościową sytuację rozwojowa. W obszarze mobilności i transportu analizy trendów wskazują na stale rosnącą flotę pojazdów, nasilające się przewozy towarów i osób, ciagłe przesuwanie się głównego trendu $\mathrm{w}$ transporcie osób $\mathrm{z}$ transportu zbiorowego $\mathrm{w}$ kierunku indywidualnego transportu zmotoryzowanego, a $\mathrm{w}$ transporcie towarowym $\mathrm{z}$ transportu szynowego $\mathrm{w}$ 
kierunku transportu drogowego i lotniczego. Rezultatem tych zmian jest z jednej strony wzrastające zużycie energii i wzrost emisji gazów cieplarnianych w sektorze transportu, z drugiej wzrost udziału wydatków na transport w budżecie państw i indywidualnych gospodarstw domowych. Te efekty są bezpośrednio sprzeczne z międzynarodowymi, krajowymi i sektorowymi agendami środowiskowymi i pośrednio sprzeczne $z$ programami oszczędnościowymi związanymi $\mathrm{z}$ przechodzeniem społeczeństw i gospodarek na zasilanie ze źródeł odnawialnych ${ }^{8}$. Dzięki podnoszeniu standardów środowiskowych w przemyśle uzyskano natomiast znaczące postępy w ograniczaniu innych źródeł emisji, między innymi eutrofizacji i emisji węglowodorów niemetanowych (NMHC) oraz w redukcji zużycia zasobów nieenergetycznych. W ostatnich latach dzięki wprowadzeniu związanych $\mathrm{z}$ technologiami komputerowymi nowoczesnych systemów bezpieczeństwa i zarządzania bezpieczeństwem, zaostrzeniu regulacji prawnych i systemom monitoringu udało się nieznacznie obniżyć liczbę ofiar śmiertelnych i rannych w transporcie w przeliczeniu na kilometr. Ciągle jednak na wysokim poziomie utrzymuje się liczba ofiar śmiertelnych i rannych w transporcie drogowym. Na płaszczyźnie obciążenia hałasem, głównie za sprawą transportu drogowego, można zaobserwować efekty wysokiego obciążenia o charakterze stagnacyjnym. Pilnych działań wymaga również kwestia wzrastającej presji na tereny ze strony systemów transportowych. Ciagła rozbudowa wolumenu tras lądowych i infrastruktur transportowych (lotniska, parkingi, drogi dojazdowe itp.) ogranicza możliwości racjonalnej i społecznie bezkonfliktowej gospodarki przestrzennej. Z jednej strony kwestie równości szans i partycypacji ludności w planowaniu przestrzennym, a z drugiej kwestie indywidualnej swobody poruszania się w przestrzeni publicznej wyznaczają dwuosiową płaszczyznę społecznych aspektów systemu transportowego, która odzwierciedla wzorce dyskryminacyjne znane z innych obszarów aktywności społecznej: dostępność możliwości transportowych i związana z nimi dystrybucja uciążliwości dla środowiska są skrajnie asymetryczne i wyznaczone w przybliżeniu przez te same pozamerytoryczne kryteria różnicujące, które determinują sytuację w obszarze edukacji czy zatrudnienia: płeć, wiek czy współrzędne geograficzne położenia.

W obszarze aktywności społecznej „mieszkalnictwo i budownictwo” mimo generalnie stosunkowo dobrego zaopatrzenia w przestrzeń mieszkalną wciąż istnieją grupy ludności, które są dyskryminowane lub zagrożone wykluczeniem: osoby samotne lub samotnie wychowujące dzieci, rodziny wielodzietne, sieroty, osoby ubogie czy imigranci. Tego typu nierównowagi społeczne mogą być źródłem zagrożeń dla bezpieczeństwa

\footnotetext{
${ }^{8}$ Pieniędzy wydanych na rosnące koszty transportu zabraknie państwom, przedsiębiorstwom i gospodarstwom domowym w innych sektorach wydatków, w tym na pokrycie rosnących kosztów zaopatrzenia w energię ze źródeł odnawialnych. Na przykład według szacunków Niemieckiego Instytutu Badań Ekonomicznych (DIW, Deutsches Institut für Wirtschaftsforschung) w Berlinie wdrożenie unijnej dyrektywy o energii odnawialnej spowoduje, że cena giełdowa prądu skorygowana o wskaźnik inflacji wzrośnie do 2020 r. o około $11 \%$ (por. T. Traber, C. Kemfert, J. Diekmann, Strompreise: künftig nur noch geringe Erhöhung durch erneuerbare Energien, „Wochenbericht des DIW Berlin”, 2011/6, s. 2-9). Symulacja DIW zakłada, że produkcja prądu ze źródeł odnawialnych w okresie 2010-2020 wzrośnie dwukrotnie, a wzrastające koszty „techniczne” produkcji i dystrybucji prądu ze źródeł odnawialnych będą kompensowane na rachunku odbiorcy malejącym opodatkowaniem. W 2010 roku koszty techniczne produkcji i dystrybucji prądu stanowiły w Niemczech jedynie $34,6 \%$ ceny prądu dla gospodarstw domowych, pozostałą część rachunku stanowiły między innymi opłaty koncesyjne $(6,5 \%)$, podatek energetyczny $(8,7 \%)$, podatek VAT $(16 \%)$, opłaty sieciowe netto $(21,4 \%)$, koszty opomiarowania i rozliczeń (3,6\%) (por. Bundesnetzagentur, Monitoringbericht 2010, Bonn 2010).
} 
społecznego i bezpieczeństwa wewnętrznego państwa. Rosnący popyt na przestrzeń mieszkalną, mimo demograficznej stagnacji, jest jednym z najważniejszych czynników presji na tereny. Stanowi również przyczynę stabilizacji na wysokim poziomie poziomu zużycia energii ze źródeł nieodnawialnych oraz poziomu wynikających stąd emisji, nawet pomimo postępującej termomodernizacji budynków. Nierozwiązany pozostaje także problem utrzymującej się wysokiej materiałochłonności sektora budowlanego. W Niemczech, podobnie jak w Polsce, nie przyjęło się budownictwo drewniane, które pozwala ograniczyć wysokoenergochłonne i wysokoemisyjne procesy termiczne związane z tradycyjnymi technologiami cementowymi i ceramicznymi oraz ich uciążliwy dla środowiska przeładunek, w zamian utrwalając i wycofując $\mathrm{z}$ obiegu w przyrodzie spore porcje dwutlenku węgla zmagazynowanego w drewnie. Problemu spalania kopalnych nośników energii w sektorze mieszkalnictwa i wysokiego poziomu emisji $\mathrm{CO}_{2}$ nie rozwiązuje zastapienie węgla czy oleju jako paliwa przez drewno opałowe. Aby przeciwdziałać tym niekorzystnym trendom, należałoby promować budownictwo drewniane i generalnie odchodzić od nowego budownictwa w kierunku bardziej zachowawczej modernizacji istniejącej substancji budowlanej, a także odchodzić od budownictwa indywidualnego w kierunku budownictwa wielorodzinnego i społecznego. W przyszłości nie będzie to jednak możliwe bez odpowiednich, daleko idących zmian istniejących uwarunkowań prawno-politycznych.

W obszarze gospodarki żywnościowej i rolnictwa najbardziej priorytetowym celem w wymiarze globalnym jest zmniejszenie problemu głodu na świecie, to znaczy możliwie szybkie i zauważalne obniżenie odsetka ludności głodującej. Nie widać jednak ani w krajach trzeciego świata, ani w krajach uprzemysłowionych specjalnego zaangażowania w zwalczanie zjawiska głodu. Głównym czynnikiem uniemożliwiającym realizację tego milenijnego celu na poziomie instytucjonalnym jest niewłaściwa polityka rolna w krajach uprzemysłowionych. Wyrazistym przykładem ostrej sprzeczności pomiędzy strategiami zrównoważonego rozwoju a polityką rolną jest wspólna polityka rolna Unii Europejskiej, która pod pretekstem stabilizacji rynku i ochrony producentów stosuje skomplikowane systemy dopłat, kwot produkcyjnych i opodatkowania, uniemożliwiających produkcję nadwyżek żywności i dzielenie się nimi z krajami walczącymi $\mathrm{z}$ problemem głodu. Również panujące obecnie w uprzemysłowionych społeczeństwach uwarunkowania rynkowe utrwalają $\mathrm{w}$ społeczeństwie niewłaściwe nawyki żywieniowe. Podstawą diety są pokarmy przemysłowo przetworzone i utrwalone, głównie mięsne, o niewielkiej wartości odżywczej i smakowej. Powrót do diety dawnych pokoleń opartej w większej mierze na pokarmach roślinnych, rybach i owocach morza oraz rezygnacja $\mathrm{z}$ masowej hodowli zwierząt ubojowych pochłaniającej większą część biomasy produkowanej w rolnictwie pozwoliłyby przy dzisiejszej wysokiej wydajności produkcji roślinnej uwolnić olbrzymie zasoby żywności, które z pewnością wystarczyłyby do tego, aby każdy żyjący obecnie człowiek na świecie codziennie najadł się do syta. Ze względu na zagrożenia zdrowia konsumentów wynikające $\mathrm{z}$ chemizacji rolnictwa, a od niedawna $\mathrm{z}$ upowszechniania inżynierii genetycznej $\mathrm{w}$ sektorze produkcji żywności należałoby $\mathrm{z}$ większą starannością kontrolować jakość żywności i podnieść standardy informacyjne i komunikacyjne w branży spożywczej, szczególnie zaś poprawić oznakowanie żywności. Nie bez znaczenia z punktu widzenia zrównoważoności w rolnictwie są, oprócz kwestii toksykologii ekosystemów rolnych, erozji gleb, zanieczyszczenia wód gruntowych, emisji gazów cieplarnianych i szkodliwego oddziaływania nowoczesnych monokultur rolniczych na bioróżnorodność, również 
sprawy energochłonności i problem odpadów. Gwałtowne restrukturyzacje w agrobiznesie zagrażają możliwości samodzielnego zabezpieczenia bytowego ludności z terenów wiejskich. Globalizacja rynku rolnego utrwala i reprodukuje nierównowage między silnymi a słabymi, a procesy koncentracyjne na rynku rolnym pozbawiają drobnych wytwórców i drobny handel większych szans udziału we współzawodnictwie i grożą monopolizacją tego sektora. Wiele krajów, również tych wysoko rozwiniętych jak Niemcy, wciąż nie stworzyło spójnej i konsekwentnej polityki żywnościowej ${ }^{9}$.

Problemy ze zrównoważonością czwartego obszaru społecznego, jaki stanowią czas wolny i turystyka, mają w stosunku do poprzednich nieco mniejszą wagę i sprowadzają się w istocie do "transportowego" aspektu dominujących zachowań społecznych w tym obszarze: indywidualnego transportu zmotoryzowanego lub transportu lotniczego. Szczególnie rosnąca popularność i coraz bardziej masowa dostępność wycieczek lotniczych - nowej formy konsumpcjonizmu - stwarza bariery na drodze do zrównoważonego rozwoju. Jest źródłem zagrożeń dla zdrowia ludzi (ekspozycja na hałas, skażenie mikropyłowe i ozonowe), niszczy klimat (emisje $\mathrm{CO}_{2}$ ), nieproporcjonalnie zużywa zasoby nieodnawialne, zagraża bioróżnorodności. Przyczynia się do wtórnej presji na wszystkie typy terenów: obszary osadnictwa, tereny zajęte przez infrastrukturę transportową, obszary leśne, rolnicze, wodne itd. Duży udział turystyki w zmotoryzowanym transporcie drogowym można traktować jako czynnik pochłaniający tereny i napędzający rozbudowę infrastruktury transportowej, zwłaszcza w tradycyjnych regionach turystycznych. Wtórna presja na tereny ze strony turystyki zagraża natomiast różnorodności gatunkowej. Koncentracja ruchu turystycznego $\mathrm{w}$ regionach atrakcyjnych przyrodniczo, stwarzając popyt na miejscowe produkty, przyczynia się do ekspansji rolnictwa na tereny cenne przyrodniczo, a aktywności, takie jak turystyka wędrowna, rowerowa czy narciarska, prowadzą do zapuszczania się turystów w miejsca o dużym znaczeniu dla ochrony bioróżnorodności. Na terenach o wysokiej wartości ekologicznej cechujących się znaczną liczbą rzadkich lub chronionych gatunków turystyka staje się głównym czynnikiem zagrażającym bioróżnorodności. Z kolei jednak turystyka, czerpiąc korzyści z atrakcyjnego przyrodniczego uposażenia takich terenów, stanowi zarazem ważne źródło dochodów dla miejscowej społeczności, bez którego trudno byłoby przeciwdziałać wyludnianiu się tych terenów albo jeszcze bardziej rabunkowej gospodarce tymi zasobami (na przykład wycinki cennych obszarów leśnych dla pozyskania drewna opałowego), a tym samym stwarza ekonomiczne podstawy dla zachowania tych cennych przyrodniczo terenów. Zrównoważony rozwój turystyki wymaga umiejętnego poszukiwania kompromisów między takimi formami użytkowania.

\section{PROGNOZY ZRÓWNOWAŻONEGO ROZWOJU NIEMIEC DO ROKU 2020}

Istnieje wiele możliwych scenariuszy przyszłości. Jedne są bardziej, drugie mniej optymistyczne pod względem szans na realizację zrównoważonego rozwoju i tempa przebiegu tych procesów. W zależności od tego, która siła: (1) rynek, (2) świat polityki czy (3) ruchy społeczne, odegra wiodącą rolę w kształtowaniu przyszłości, można te

\footnotetext{
${ }^{9}$ Nachhaltigkeitsprobleme in Deutschland. Analyse und Lösungsstrategien..., s. 25.
} 
możliwe opcje, upraszczając, zredukować do trzech głównych scenariuszy eksploracyjnych $^{10}$ :

1) Scenariusz „rynkokratyczny”"11. Dominującą rolę czynnika determinującego rozwój odgrywa „rynek”. Nasilający się proces ekonomicznej globalizacji z mechanizmami rynkowymi jako zdecentralizowanym systemem sterowania (w sensie „władzy bez ośrodka”) wymusza na społeczeństwie zorientowaną podażowo politykę gospodarczą w formie zachowania adaptacyjnego. Elementem tej polityki jest odbarczenie przedsiębiorstw $\mathrm{w}$ zakresie opodatkowania i składek społecznych w celu zapewnienia im konkurencyjności w warunkach międzynarodowej wymiany. Zarówno sprawy środowiskowe, jak i sprawy społeczne odgrywają rolę drugoplanową. Kryteria ekonomiczne dochodu, własności i siły nabywczej stają się głównym czynnikiem strukturalizacji i stratyfikacji społecznej. Społeczeństwo zostaje zredukowane do siły roboczej i konsumentów. Źródła szczęścia i osobistej realizacji ludzie upatrują w maksymalizacji dochodów uzyskiwanych z wysoko wydajnej pracy najemnej i nabywanie dóbr w celu zaspokajania potrzeb. Prymat egoizmu, hedonizmu i orientacji na wydajność nie pozostawia miejsca na solidaryzm społeczny i działanie na rzecz wspólnego dobra. Trendy desocjalizacyjne i indywidualizacyjne równoważy homogenizacja oferty towarów, usług i stylów życia, której symbolem jest powszechna makdonaldyzacja ${ }^{12}$ (choć nie istnieje wspólnota, to i tak wszyscy myślą i postępują tak samo).

2) Scenariusz „modernizacyjny”. Kluczową rolę w kształtowaniu przyszłości odgrywa polityka towarzysząca procesowi postępującej ekonomicznej globalizacji. Polityka nie jest jednak rozumiana klasycznie w sensie arystotelesowskiego modelu służby na rzecz wspólnego dobra w warunkach najwyższego rangą naturalnego związku ludzi opartego na stosunkach podporządkowania i współdziałania $^{13}$, ale w sposób nowożytny, „makiawelowsko-hobbesowski”, jako sztuka zdobywania i utrwalania przewagi w „wojnie wszystkich przeciw wszystkim”. Celem takiej polityki jest wykorzystanie szans, jakie niesie globalizacja, i zapobieganie zagrożeniom wynikającym z procesów globalizacyjnych. Polityka gospodarcza w tym scenariuszu dąży do zapewnienia sprawiedliwości społecznej i społecznej kompensacji pod hasłem bezpieczeństwa państwa i zapobiegania zagrożeniom ekologicznym za pomocą innowacyjnych technologii i podnoszenia efektywności. Odpowiedzialność za zrównoważony rozwój ponoszą instytucje publiczne. Wdrażanie zrównoważonego rozwoju polega na działaniach

\footnotetext{
${ }^{10}$ Ibidem, s. 27 n.

${ }^{11}$ Por. J. Daszkiewicz, Wczesne tendencje rynkokratyczne w refleksjach nad kapitalizmem, „Zeszyty Naukowe Politechniki Rzeszowskiej. Ekonomia i Nauki Humanistyczne" 219/14 (2004), s. 9-16.

${ }^{12}$ Zob. więcej G. Ritzer, The McDonaldization of Society, SAGE Publications, Inc., Thousand Oaks 1993. Pod pojęciem „makdonaldyzacji” rozumie się wszystkie procesy ekonomiczne, społeczne i kulturowe, które towarzyszą ekspansji prostych reguł biznesowych, takich jak maksymalizacja zysków i wydajności przy minimalnych kosztach i minimalnej jakości, homogenizacja oferty, wysokie obroty, wysoki stopień kompresji i penetracji rynku zapewniajace kontrolę nad konsumentem, reguł, które okazały się receptą na sukces amerykańskiej sieci barów przekąskowych, na wiele innych pozabiznesowych dziedzin życia społecznego, takich jak edukacja, praca, polityka, życie towarzyskie czy wypoczynek.

${ }^{13}$ Por. Arystoteles, Polityka, 1253a n.
} 
legislacyjno-administracyjnych. Warunkiem skuteczności tych działań nie są zmiany w świadomości społecznej ani zmiany indywidualnych postaw czy stylu życia, ponieważ procesy te są instytucjonalnie „zaprogramowane”.

3) Scenariusz „regionalizacja i reorientacja na wspólne dobro” zakłada, że największy wpływ na realizację zrównoważonego rozwoju mają działania „oddolne”, bazujące na zmianach wyobrażeń aksjologicznych w społeczeństwie, nowej świadomości, upowszechnianiu się rozumienia wspólnego dobra, solidaryzmu, odpowiedzialności i współodpowiedzialności za innych, za przyszłość i za środowisko. Oddolne procesy samoorganizacyjne społeczeństwa neutralizują deterministyczne mechanizmy ekonomii, a w warunkach demokracji wyborczej i społeczeństwa obywatelskiego powodzenie działań politycznych i tak ostatecznie zależy od woli i gotowości większości społeczeństwa do wyrzeczeń i ograniczeń, jakich wymagają z jednej strony ochrona środowiska, a $\mathrm{z}$ drugiej społeczna kompensacja i programy socjalne. Polityka ma w tym scenariuszu charakter zależny, służebny i „popytowy”. Rdzeniem tego scenariusza są procesy emancypacyjne $\mathrm{w}$ społeczeństwie nabudowane na ideach partycypacyjnych $\mathrm{i}$ indywidualnej aktywności obywatelskiej ${ }^{14}$. Czynniki ekonomiczne są wtórne, zależne od procesów samoorganizacyjnych w społeczeństwie. Na przykład kwestie zabezpieczenia społecznego zostają w dużej mierze uniezależnione od czynnika mikroekonomicznego, jakim jest praca, $\mathrm{i}$ otrzymują nowe, o wiele szersze podstawy socjoekonomiczne. Spada szacunek dla działalności zarobkowej na korzyść wzrostu społecznego uznania dla wolontariatu i pracy socjalnej, które honoruje nawet samo państwo. Działalność prospołeczna i proekologiczna staje się domeną partnerstwa między instytucjami państwa a instytucjami społeczeństwa obywatelskiego - organizacjami pozarządowymi.

Wykorzystując model symulacyjny PANTA RHEI ${ }^{15}$ Instytutu Ekonomicznych Badań Strukturalnych Sp. z o.o. (GWS, Gesellschaft für Wirtschaftliche Strukturforschung mbH) przy Uniwersytecie w Osnabrück bazujący na pięciu wskaźnikach (bezrobocie, zadłużenie państwa, emisje $\mathrm{CO}_{2}$, zużycie zasobów nieodnawialnych i zużycie terenów), podjęto próbe prognozowania rozwoju deficytów zrównoważoności do 2020 r. osobno dla każdego z trzech scenariuszy eksploracyjnych. Rezultatem symulacji jest przede wszystkim zaskakujące odkrycie, że w wypadku scenariusza „rynkokratycznego” wzrost gospodarczy, będący głównym celem polityki gospodarczej zorientowanej podażowo, wcale nie jest wyższy niż w wypadku scenariusza „,modernizacyjnego”. Stopa bezrobocia w 2020 r. jest tylko nieznacznie niższa niż w roku 2000. Natomiast wyraźniejsza jest koncentracja dochodu i majątku przy rosnących dysproporcjach dochodowych. Dzięki stopniowemu wycofywaniu się państwa $\mathrm{z}$ wielu dotychczasowych zadań udaje się osiagnąc cele związane z deficytem budżetowym. Za to nieciekawie wypadają wskaźniki środowiskowe. W szybkim tempie następuje wzrost emisji $\mathrm{CO}_{2} \mathrm{i}$ wzrost zużycia

\footnotetext{
${ }^{14}$ Więcej na temat procedur partycypacyjnych i ich znaczenia dla demokracji zob. K. Michalski, Uczestnictwo obywateli w publicznych procesach decyzyjnych jako forma aktywności obywatelskiej na przykładzie partycypacyjnej oceny technologii (pTA), [w:] R. Klamut i in. Aktywność obywatelska we współczesnym spoteczeństwie demokratycznym. Wybrane zagadnienia, SEITON, Kraków 2010, s. 59-110.

${ }^{15}$ B. Mayer, The economic-environmental model Panta Rhei and its application, „GWS Diskussion Paper” 2005/3
} 
kopalnych nośników energii, jeszcze szybciej wzrasta zużycie terenów. Jeśli rozwój przebiegnie według tego scenariusza, to obecne deficyty zrównoważoności jeszcze bardziej się pogłębią ${ }^{16}$. W wypadku scenariusza „modernizacyjnego" należy się spodziewać osiągnięcia celów ekonomicznych w odniesieniu do wzrostu i deficytu budżetowego. Należy się spodziewać złagodzenia problemu bezrobocia, jednak w niewystarczającym stopniu. W odniesieniu do wskaźników środowiskowych udaje się osiągnąć nieznaczne obniżenie zużycia nieodnawialnych surowców energetycznych przy jednoczesnej krótkoterminowej (do 2012 r.) realizacji celów emisyjnych wynikających z Protokołu z Kioto i przy stagnacji tempa zużycia terenów na wysokim poziomie. Natomiast z realizacją scenariusza „regionalizacja i reorientacja na wspólne dobro” związane jest znaczne obniżenie tempa wzrostu. Bardziej sprawiedliwy podział dochodu przy spadającej wydajności nadal nie zapewni każdemu gospodarstwu domowemu wystarczających dochodów. Dzięki wzrostowi zatrudnienia w niepełnym wymiarze i subwencjom na prace społeczne można się spodziewać poszerzenia rynku pracy i zbliżenia do celów związanych ze wskaźnikiem bezrobocia, ale ze względu na negatywne trendy wzrostowe realizacja ambitniejszych celów społecznych i środowiskowych jest zagrożona, szczególnie tam, gdzie jest uzależniona od szybkiego rozwoju regionalnych struktur ekonomicznych. Wydaje się, że społecznie i ekonomicznie bezkolizyjny przebieg procesów transformacyjnych zakładanych w tym ostatnim scenariuszu wymaga dłuższego horyzontu czasowego niż przyjęty w programowaniu rozwoju rok $2020^{17}$.

Na podstawie wyników symulacji obliczono następnie wartości wskaźników osobno dla wszystkich czterech referencyjnych obszarów społecznej aktywności. Okazało się, że trendy zidentyfikowane $\mathrm{w}$ szczegółowych obszarach $\mathrm{w}$ pełni pokrywały się $\mathrm{z}$ trendami stwierdzonymi w diagnozie całościowej. Analiza egzemplaryczna wyróżnionych obszarów aktywności społecznej nie ma jednak na celu wyłącznie uzyskania potwierdzenia powszechnego, uniwersalnego charakteru danego trendu. Służy ona przede wszystkim poszukiwaniu rozwiązań i identyfikacji niewykorzystanych potencjałów, które nie tylko można spożytkować do programowania zrównoważonego rozwoju danego sektora, ale które mają również wartość ekstrapolacyjna, to znaczy uzyskaną w ten sposób wiedzę można wykorzystać do rozwiązywania problemów w innych obszarach.

Niewątpliwą zaletą integracyjnej koncepcji zrównoważonego rozwoju jest, oprócz jej wysokiej wartości implementacyjnej, wydajności ewaluacyjnej i uniwersalnego charakteru, wysoka kultura metodologiczna przejawiająca się samoświadomością i samorefleksywnością procedur, surowym reżimem legitymizacyjnym i opanowaniem heterogenicznych narzędzi badawczych. Jak każda próba interdyscyplinarnej syntezy koncepcja integracyjna walczy z normalnymi problemami metodologicznymi związanymi ze wzajemną niekompatybilnością wykorzystywanych metod i nieprzystawalnością i nieprzekładalnością uzyskiwanych $\mathrm{w}$ ten sposób rezultatów ${ }^{18}$. Dzięki właściwemu metodologicznemu oznakowaniu tych krytycznych momentów i dzięki jej programowej tolerancji na błędy i otwartości na korekty koncepcja integracyjna neutralizuje ewentualne zarzuty. Z pewnością warto byłoby również w programowaniu i monitorowaniu

\footnotetext{
${ }^{16}$ Por. Nachhaltigkeitsprobleme in Deutschland. Analyse und Lösungsstrategien..., s. 27.

${ }^{17}$ Ibidem.

${ }^{18}$ Więcej na temat metodologicznych problemów związanych z interdyscyplinarnością zob.: K. Michalski, Interdyscyplinarność - transdyscyplinarność - multidyscyplinarność. Nowy paradygmat w nauce i badaniach „Zeszyty Naukowe Politechniki Rzeszowskiej. Ekonomia i Nauki Humanistyczne” 235/16 (2007), s. 83-100.
} 
zrównoważonego rozwoju $\mathrm{w}$ warunkach polskich sięgnąc po te gotowe, sprawdzone rozwiązania.

\section{LITERATURA}

[1] Borys T., W poszukiwaniu syntetycznego wskaźnika zrównoważonego rozwoju, [w:] Obszary badań nad trwalym i zrównoważonym rozwojem, red. Poskrobko B., Ekonomia i Środowisko, Białystok 2007, s. 271-292.

[2] Bundesnetzagentur, Monitoringbericht 2010, Bonn 2010.

[3] Daszkiewicz J., Wczesne tendencje rynkokratyczne w refleksjach nad kapitalizmem, „Zeszyty Naukowe Politechniki Rzeszowskiej. Ekonomia i Nauki Humanistyczne” 219/14 (2004), s. 9-16.

[4] Jörissen J., Kneer G., Rink D., Wissenschaftliche Konzeptionen zur Nachhaltigkeit, [w:] Forschungswerkstatt Nachhaltigkeit. Wege zur Diagnose und Therapie von Nachhaltigkeitsdefiziten, red. Grunwald A. i in., Edition Sigma, Berlin 2001, s. 33-58.

[5] Kopfmüller J. i in., Nachhaltige Entwicklung integrativ betrachtet. Konstitutive Elemente, Regeln, Indikatoren, Edition Sigma, Berlin 2001.

[6] Mayer B., The economic-environmental model Panta Rhei and its application, „GWS Diskussion Paper" 2005/3.

[7] Michalski K., Interdyscyplinarność - transdyscyplinarność - multidyscyplinarność. Nowy paradygmat w nauce i badaniach, „Zeszyty Naukowe Politechniki Rzeszowskiej. Ekonomia i Nauki Humanistyczne" 235/16 (2007), s. 83-100.

[8] Michalski K., Uczestnictwo obywateli w publicznych procesach decyzyjnych jako forma aktywności obywatelskiej na przykładzie partycypacyjnej oceny technologii (pTA), [w:] Klamut R. i in., Aktywność obywatelska we współczesnym spoleczeństwie demokratycznym. Wybrane zagadnienia, SEITON, Kraków 2010, s. 59-110.

[9] Nachhaltigkeitsprobleme in Deutschland. Analyse und Lösungsstrategien, red. R. Coenen, A. Grunwald, Edition Sigma, Berlin 2003.

[10] Ritzer G., The McDonaldization of Society, SAGE Publications, Inc., Thousand Oaks 1993.

[11] Traber T., Kemfert C., Diekmann J., Strompreise: künftig nur noch geringe Erhöhung durch erneuerbare Energien, „Wochenbericht des DIW Berlin” 2011/6, s. 2-9.

\section{INTEGRATION CONCEPT OF SUSTAINABLE DEVELOPMENT (IKoNE)}

The article presents the little-known in Poland integration concept of sustainable development (IKoNE) developed in the late nineties of the twentieth century by the Federation of German Research Centres of Hermann Helmholtz. Against the background of the methodological characteristics there are examples of successful applications of this concept to diagnose the situation of Germany in terms of development of the main shortcomings of sustainability and looking for their solutions.

Keywords: sustainable development, IKoNE.

DOI:10.7862/rz.2012.einh.19 